\title{
Application of the Concept of Eco Office Building at Library of Users Universitas Sumatera Utara
}

\author{
Himma Dewiyana ${ }^{1}$ and Bandot Sumardiyono ${ }^{2}$ \\ \{himma.dewiyana@usu.ac.id\} \\ ${ }^{1}$ Department Library and Information Science, Universitas Sumatera Utara, Jl. Perpustakaan No. 3, \\ Medan, Indonesia \\ ${ }^{2}$ Arsip Nasional Republik Indonesia Jl Ampera RayaNo. 7 Jakarta, Indonesia
}

\begin{abstract}
This study aims to determine the application of the concept of eco office building Library of University of Sumatera Utara. The study used quantitative descriptive approach. The sample in this study is the USU library visitors and staff. The total sample of 100 respondents. The instrument used in this study a questionnaire responses. The instrument has been tested the validity and reliability so that the instrument can be said to qualify for research data retrieval tool. Analysis of experimental data using analysis of the percentage credit point. Five indicators of the application of the concept of eco office that has been tested, namely, saving electricity, saving and water conservation, waste management office, greening, other efforts, the outcome boiled down to a score of $77.43 \%$, which shows that the application of the concept of eco office in USU library building is quite accomplished. The distribution rate of implementation of the application in accordance with the application indicator is the savings of electricity (60.31\%), savings and water conservation (61.53\%), waste management office (84.44\%), afforestation $(85.83 \%)$, more attempts $(55.07 \%)$.
\end{abstract}

Keywords: Eco Office, Library Building, Universitas Sumatera Utara, Environmental Management System

\section{Introduction}

According to the web site address of the Environment Agency (BLH) eco office or agency concerned about the environment is a reflection of an office policy that implements an Environmental Management System (EMS) in order to create a working environment clean and comfortable office which involves all the activities of individuals who are in office. Eco office has many perceived benefits both the employees and managers of government offices that implement eco office in accordance with the advice of the government through Presidential Decree No. 2/2008 dated May 5, 2008. Minister of Public Works and Instruction of 2008 on Saving Energy and Water.

Especially buildings that daily visited by many students and visitors as one example is the library building. The library is a place where every person who wants to find books to suit the wishes and needs. People who are reading or looking for a book in a library require a state of comfortable and quiet so relaxed when doing activities in the library. USU library consists of 4 floors. The background of the application of the concept of eco office based on the behaviour of employees and users of the library building is based on a desire to know the 
extent of the application of environmentally friendly library and provide convenience for library users. Whether the application of the concept of eco office library has been achieved or not? Meanwhile, according to the Green Building Council Indonesia (GBCI) there are five aspects of an office could be said to have the concept of eco office that consideration for the health and well-being, a high level of comfort, design following the change, the use of the latest technology, and human resources training (GBCI, 2010). How the application of the concept of eco office building based on user behaviours USU Library?

Understanding of the application of the concept of eco office building of the library is to delve deeper into the actions taken to understand the building libraries that collaborate with the environment so that the library can be run as usual without having to pollute the environment (Higde, 2014).

To determine the extent of the application of the concept of eco office at USU library. Benefits in Theoretically can give feedback to the user of the library building to carry out the implementation of the concept of eco office. In practical terms can be rule-based governance eco office.

\section{Eco Library Building}

According to the Constitution No. 43 of 2007 Article 1, paragraph 1: The library is an institution managing the collection of paper, printing paper, and/or recorded works professionally with a standard system to meet the needs of education, research, preservation, information and recreation of the users. College libraries are libraries that are in the environment of higher education institutions such as universities, institutes, high schools, colleges and other higher education institutions. Furthermore, Library College is incorporated in the library environment of higher education institutions, both in the form of universities libraries, faculty libraries, college libraries, high school library. The goal is to help universities in carrying out the teaching program (Hermawan and Zulfikar, 2006; Syahrial-Pamuntjak, 2000). While understanding the other in the Handbook for College Libraries, Ministry of Education $(2004,3)$ College libraries are supporting element colleges, which together with other supporting elements, participate in implementing the achievement of the vision and mission of the college. Referred to college is a university, college, high school, colleges, polytechnics and other colleges are equal.

Users are people who use something. Here the intent of the user is the person using and making the facilities at USU library consisting of employees, visitors and readers.

According to the National Standardization ISO 7330: 2009, the standards for libraries in higher education are as follows: The library provides the building with ample space for collective, staff and users. Libraries should be at least $0.5 \mathrm{~m} 2$ for each student. The area covering $45 \%$ collection which consists of a collection of books, multimedia room, space collection scientific magazines. The user space of $30 \%$, consisting of a reading room with a reading table, a reading table, special reading room, discussion room, catalogue/computer, the circulation desk, day-care bags and toilet. Space covering $25 \%$ of library staff consists of the processing room, bindery room, meeting room, storage room newly received books, kitchen and toilet.

Behaviour is the individual responses or reactions to stimuli or environmental (Higde, 2014). From the view of the biological behaviour of an activity or activities of the organism in question. Behaviour is actions or deeds of an organism that can be observed and can even be 
studied. Behaviour is the person's response or reaction to the stimulus / stimuli from the outside. Therefore, this behaviour occurs via the process of the organism. And then the organism to respond, Skinner's theory is called "S-O-R" or stimulus-organism-response.

\section{$2.1 \quad$ Eco Office}

Eco office comes from abbreviating the word "Ecology" and "Office" means an office where care for the environment which has put the implementation of environmental management systems in the activities office accommodation as well as improve the effectiveness and efficiency of use of natural resources available. On the other hand, the notion of eco office according to the web site of the Environment Agency (BLH), as the office is concerned about the environment which is a reflection office policy that implements an environmental management system (ISO 14005:2010). Based Green Building Council Indonesia (GBCI), there is five aspects of an office could be said to have the concept of Eco Office, among which: First, consideration for the health and well-being. Based on data from the Green Office Network founded by WWF in 2010, 119 Office managed to reduce electricity consumption to reach 2.9 million KWh than in 2009.

Secondly, a high level of comfort. The convenience factor includes terms of visual, acoustic, and thermal for the occupants. An example for visual comfort is designing a room that has a natural impression that the room would look fresh and lively. Minimizes noise from HVAC systems (Heating, Ventilation and Air Conditioning), including efforts to create comfort in terms of acoustics. Meanwhile, avoid hot spots of sunlight through the placement of proper ventilation is for the sake of convenience in terms of thermal.

Third, the design follows the changes. When the function of a room you want to replace, do not need to revamp the massive but small change is enough. It is very efficient and helpful as could minimize electronic waste and furnishings.

Fourth, the utilization of the latest technology. The technology used is usually a wireless technology (wireless) as well as the use of optical fibres cables for data transmission and Internet-based video conferencing. The use of technology such as this can reduce the use of paper. In addition, the use of information technology equipment that is durable and energy saving also needs to be implemented.

Fifth, training of human resources. This training could be one of them how to use a particular technology. This is very important because any sophisticated technology, if not used properly, the benefits of these technologies will not be maximized and can even be damaged.

Green Building is a concept in the development of an environmentally friendly building (Delinchant, 2016). The implementation of Green Building, there is six aspects/parameter (Appropriate Site Development, Energy Efficiency and Conservation, Water Conservation, Material Resources and Cycle, Indoor Health and Comfort, and, Building Environment Management) called the rating system is greenship Indonesia. Greenship an assessment tools developed by the Green Building Council of Indonesia (GBCI) to determine whether a building can be declared eligible certified "green building" or not.

\subsection{Green Behaviour}

According to the pocket book of 2008 the ministry of public works agencies coaching centre construction coaching competence and training in construction, the important thing to do to achieve environmentally friendly offices is the change in user behaviour office for more attention to environmental protection, from us, from things small. 


\subsubsection{Power Savings}

Reducing the use of incandescent light bulbs, and take advantage of sunlight through the window. Reducing the use of $\mathrm{AC}$ (air conditioner) to start the air-conditioning at $10 \mathrm{am}$, and set the room temperature around $22-25^{\circ} \mathrm{C}$. Turn off the room lights and computer work during lunch breaks and after work. Replacing garden lamps, with energy-saving lamps. Using solar panels for hot water supply.

\subsubsection{Savings and Water Conservation}

Encouragement to use water as necessary and to tap on minimum water discharge. Using a bath with shower. Replace toilets with bidets "ecofriendly".Make biopori. Utilizing sewer water for watering plants. Planting drought resistant plants (such as Bougenville, etc.).

\subsubsection{Waste Management Office}

Provides trash disaggregated, i.e. for waste paper, for plastic waste, litter bottles/iron/aluminium, household hazardous waste, such as batteries/etc., and wet waste which can be composted. Sorting trash by category. Making compost with a simple method. In cooperation with scavenger / stall for rubbish that can be recycled. Reducing the use of plastic for lunch or entree meeting.

\subsubsection{Greening}

Things are done for reforestation include: Adding plants / trees in the yard. Greening the room with the addition of potted ornamental plants. Choosing plants that are drought resistant so as to save water. Utilizing compost organic waste processed. Watering plants with water exiles.

\subsubsection{Other efforts}

Things are done for other efforts include: The appeal not to smoke in public spaces such as in the work space, it is necessary to be prepared for a smoking room. Attaching the stickers in strategic locations which call to make savings. To disseminate to employees, and office users. Make a sticker on the theme "eco-office" to be shared. Making documentaries for socialization. Appeal wearing office clothes from materials, such as cotton but still maintain decorum.

\section{Method}

This study uses a quantitative descriptive approach. The independent variables in this study is the behavior of employees and users of the library building on the concept of eco USU office in USU Library. The dependent variable in this study is the electricity savings, savings and water conservation, waste management, greening and other efforts that support the behavior of eco office. Composed of three instruments (parameters) who wish to be known as qualitative data research. These instruments include an overview of the state of implementation of green computing on the object of research institutions, perspectives on the application of the concept of eco office as well as the implementation of the observation area. These instruments are as follows: Awareness (consciousness) and Regulation (policy).

The population in this study were employees and users USU Library building. Sampling with random sampling. Determination of the sample using the formula Slovin, then obtained a 
sample of 100 people. Sources of primary data, ie data obtained directly by means of: interviews, questionnaires and observations. Sources of secondary data obtained documentation. The following classification reliability to study the application of the concept of eco office on employees and users of the library.

Table 1. Classification Interval percent

\begin{tabular}{lll}
\hline Interval percent & Criteria & Code \\
\hline $84 \%<$ Score $\leq 100 \%$ & Already Very materialize & SST \\
$68 \%<$ Score $\leq 84 \%$ & Already Done & ST \\
$52 \%<$ Score $\leq 68 \%$ & Simply Done & CT \\
$36 \%<$ Score $\leq 52 \%$ & Less Done & KT \\
$0 \%<$ Score $\leq 36 \%$ & Not Done & TT \\
\hline
\end{tabular}

\section{Result And Discussion}

We hope you find the information in this template useful in the preparation of your submission In the study descriptive variable Application of Concept Eco Office Building, the assessment carried out by five aspects, as follows:

\subsection{Power Savings}

Table 2. Application On Power Savings Aspects

\begin{tabular}{|c|c|c|}
\hline $\begin{array}{l}\text { Eco Concept Implementation Efforts } \\
\text { Office }\end{array}$ & $\%$ & $\begin{array}{c}\text { Criteria } \\
\text { Application }\end{array}$ \\
\hline $\begin{array}{l}\text { Reducing the use of lights, and use sunlight thrsough the } \\
\text { window }\end{array}$ & 71 & Already implemented \\
\hline $\begin{array}{l}\text { Reducing the use of air conditioning (tool air conditioning) by } \\
\text { simply put the air conditioner on a particular room }\end{array}$ & 83 & Already implemented \\
\hline $\begin{array}{l}\text { Turn off the lights in the room during lunch breaks and after } \\
\text { work }\end{array}$ & 69 & Already implemented \\
\hline $\begin{array}{l}\text { Shutting down the computer at the time lunch breaks and after } \\
\text { work }\end{array}$ & 64 & Quite accomplished \\
\hline Using energy saving lamps & 48 & Less accomplished \\
\hline Using lighting the lamp taste as needed. & 74 & Already implemented \\
\hline $\begin{array}{l}\text { Distributing stickers / posters } \\
\text { in strategic locations which calls to save electricity }\end{array}$ & 45 & Less accomplished \\
\hline
\end{tabular}

Score application of the concept of eco office in USU library building at 0.60 . Implementation of the application of the concept of eco office building USU library based on the interval score indicates the criteria fairly implemented.

Saving electricity is one of the main criteria contained in the instrument of research, where the criteria is an attempt to harness electricity as needed. Electricity is the energy source that is created from other sources of energy, it will, save the user saves a lot of energy. Replacing incandescent bulbs with energy saving lamps (LHE) to the SNI logo. Some features include flame lights LHE LHE brighter than incandescent bulbs and age LHE lamp life is also longer. For natural lighting by GBCI applicability of natural light optimally so that at least $30 \%$ of floor space used exposed to natural light. Where details of the criteria for electricity savings, USU library building using energy-efficient fluorescent lamps, as well as their 
window as a source of natural light. At USU Library building no stickers or posters placed in strategic locations are urged to save electricity. For the application of electricity savings, reducing the use of lights and take advantage of sunlight through the windows are quite accomplished, reducing the use of air conditioning is very accomplished, turn off the room lights and computers during lunch break and leave work quite accomplished.

Saving energy at USU Library building has not been fully implemented. Still needs much improvement application of the concept. Such as reducing the use of light by utilizing the energy from sunlight. Still prevalent lights appear excessive. Kind of lights are used incandescent lamps. While incandescent light bulbs are not included in the group of energysaving, energy-saving besides not this type of lamp is also easily damaged, so wasteful in the purchase. Supposedly library wear energy-saving lamps that do not spend a lot of costs for electricity and the damaged lamp. To where stickers or posters about electricity savings have not been found in the library building USU. This is necessary so that in addition to taking the goods and materials that are energy efficient as well as individual that understands the environmental problems and participate in maintaining the environmental balance by applying the concept of eco office can be accomplished in the presence of a poster or sticker that explains how to save electrical energy.

The use of the window as the natural light is sufficient, the light coming in through the vents get the reflection of light from the canopy beneath it so that helped create the appropriate lighting levels with SNI. Light entering through the window can enter optimally. This is because the clear window glass can absorb solar heat and have less visibility from outside the room, but the light can still sign in to the optimum. But this is still not fully utilized by visitors to the library. This is because there should be a table and chairs near the window so that the visitors can enjoy reading a book near a window that gives natural lighting and cool air from the fresh air coming from outside.

\subsection{Saving and Water Conservation}

Table 3. Application On Criteria Saving and Water Conservation

\begin{tabular}{lcl}
\hline \multicolumn{1}{c}{ Eco Concept Implementation Efforts Office } & $\%$ & \multicolumn{1}{c}{$\begin{array}{c}\text { Criteria } \\
\text { Application }\end{array}$} \\
\hline Advise to use Water as needed & 45 & Less accomplished \\
Using the shower in every bathroom. & 28 & Not done \\
$\begin{array}{l}\text { Do not use the closet Automatic flush } \\
\begin{array}{l}\text { Distributing stickers / posters in strategic locations which } \\
\text { calls for saving water }\end{array}\end{array}$ & 71 & Already Very materialize \\
\hline
\end{tabular}

Score application of the concept of eco office in USU library building at 0.61528 . Implementation of the application of the concept of eco office building USU library based on the interval score indicates less criteria implemented.

Savings and water conservation is an attempt to use sufficient water as needed in order to conserve water. According GBCI for water conservation is done is water metering which aims to control the use of water so that it can become the basis of the implementation of better water management. The benchmark is the installation of water meters in certain places in order to control the use of clean water. Water recycling aimed at providing water from recycled wastewater derived from the building to reduce the need for water from the main source. The benchmark is a water recycling plant with a capacity sufficient for the needs of the entire system flushing, irrigation and cooling tower make-up water (if any). Where to details of saving and water conservation, USU library building does not use any shower in the 
bathroom, do not use automatic closet automatic rinsing, does not create and install stickers or posters, did not make a recommendation for the use of water as needed.

\subsection{Waste Management Office}

Table 4. Application of Criteria In Solid Waste Management Office.

\begin{tabular}{lcl}
\hline \multicolumn{1}{c}{ Application Criteria } & $\%$ & \multicolumn{1}{c}{$\begin{array}{c}\text { Criteria } \\
\text { Application }\end{array}$} \\
\hline Setting up the trash & 93 & Has been very materialize \\
Provide trash disaggregated & 74 & Already implemented \\
Provide bins in inside the building. & 82 & Already implemented \\
Prohibits bringing food or drinks in the library room & 84 & Already implemented \\
Cleaning the room and not there is garbage strewn around. & 89 & It is very materialize \\
\hline
\end{tabular}

Score application of the concept of eco office in USU Library building at 0.84 . Implementation of the application of the concept of eco office building USU library based on aspects of waste management office has been implemented.

Waste management is an attempt to menegelola and set rubbish in order to make the environment cleaner. Besides waste management is also implementing the waste disposal disaggregated. According GBCI waste management system ie Pollution of Construction Activity which aims to encourage the reduction of trash brought to landfills (TPA) and the pollution of the construction process. The benchmark is to provide a collection area, separation and recording system. Recording differentiated on the basis of solid waste disposed to landfill, reused, and recycled by third parties for solid waste and to keep quality of effluent water resulting from construction activities so as not to pollute the city drainage, effluent. Where to details of waste management office, the library building has not been used bins USU disaggregated by san inorganic organic category. The application of the concept of eco office in the category of waste management at USU Library building in accordance with the results of research, there has been no trash disaggregated consists of two categories: organic and inorganic. Bin was placed outside the library building.

\subsection{Greening}

Table 5. Application of Criteria of Greening

\begin{tabular}{lcl}
\hline \multicolumn{1}{c}{ Application Criteria } & $\%$ & Criteria Implementation \\
\hline Having a garden & 93 & Already very accomplished \\
Make a lot of parks & 95 & Already very accomplished \\
Greening the room with the addition of potted ornamental plants & 70 & Already implemented \\
\hline
\end{tabular}

Score the application of the concept of eco office in USU Library building at 0.86 . Implementation of the application of the concept of eco office building USU Library based on the interval score indicates the criteria already accomplished.

According GBCI greening is "site landscaping" that aims to maintain or expand greenery to improve the quality of the microclimate, reduce $\mathrm{CO} 2$ and pollutants; preventing soil erosion; reduce the burden on drainage systems, maintaining the balance of water and ground water systems. The benchmark is the area of landscape form of vegetation (softscape) that is free of buildings garden (hardscape) located above the ground surface area of at least $40 \%$ of total land area. The area considered is included mentioned in Condition 1, a garden on the basement, roof garden, garden terrace, and a garden wall, according to Candy PU No. 
5/PRT/M/2008 regarding green open space (RTH) of Article 2.3.1 of the criteria vegetation for courtyard. And the use of local plants (indigenous) and local-scale cultivation provinces covering $60 \%$ of the land area broad canopy of green.

Where for details greening USU Library building already contained USU park around the building and there is a garden in front of the building entrance of the building greening atmosphere USU library. The park consists of a variety of ornamental plants and dominated by elephant grass and red bud trees. There was also a palm tree as accents and red tops for shade. The existence of shade trees is widely available around the building and there are also many gazebo in the park. Shade trees for shade in addition serves also the function of regulating the level of oxygen and maintain the condition of the air from pollution. But inside the building yet there are many potted trees to make the atmosphere in the building. Potted plants live in the building serves as penghijau atmosphere and also as a regulator of oxygen levels in the building.

The application of the concept of eco office in USU library building, already are many parks around the building, there is a garden in front of the building with local plants to cultivate local plants as recommended GBCI. Such as elephant grass, palm, red bud, wali Songo, and so forth. Inside the building there is no garden or potted plants alive enough to green space.

\subsection{Other Efforts}

Table 6. Implementation In Other Efforts criteria.

\begin{tabular}{lll}
\hline Application Criteria & $\%$ & $\begin{array}{l}\text { Criteria } \\
\text { Application }\end{array}$ \\
\hline Giving a call for no smoke & 69 & Already implemented \\
Provides a dedicated space for smoker. & 34 & Not Done \\
To socialize eco office for employees, and library users. & 40 & Less Done \\
Provides collection in CD or E-Book that can be & 77 & Already implemented \\
accessed in the library & & \\
\hline
\end{tabular}

Score the application of the concept of eco office in USU library building at 0.55 . Implementation of the application of the concept of eco office building USU library based intterval score indicates less criteria implemented.

Other efforts here means the other efforts undertaken to support the implementation of the concept of eco office other than the four criteria mentioned earlier. Other efforts that call for non-smokers, providing space for smokers, socialization eco office, and paperless. No socialization eco office for employees and library users are very influential with the application of the concept of eco office in USU library building. To implement paperless for not wasting paper, the library has implemented an online presence and also E-Book for download and look for the presence of books available in the Library of USU.

Eco office is the application of environmentally friendly offices, attention to the environment and their application to each building has been set standards of behavior to achieve environmentally friendly offices. Therefore, the purpose of this study was to determine to what extent and how the application of the concept of eco office applications applied at USU Library building. 
Table 7. Application of the concept of eco office at USU Library building

\begin{tabular}{lc}
\hline \multicolumn{1}{c}{ Application Criteria } & Credit point \\
\hline Power savings (A1) & 0.60 \\
Saving and water conservation (A2) & 0.62 \\
Waste management office (A3) & 0.84 \\
Greening (A4) & 0.86 \\
More effort (A5) & 0.55 \\
\multicolumn{1}{c}{ Average } & 0.67 \\
\hline
\end{tabular}

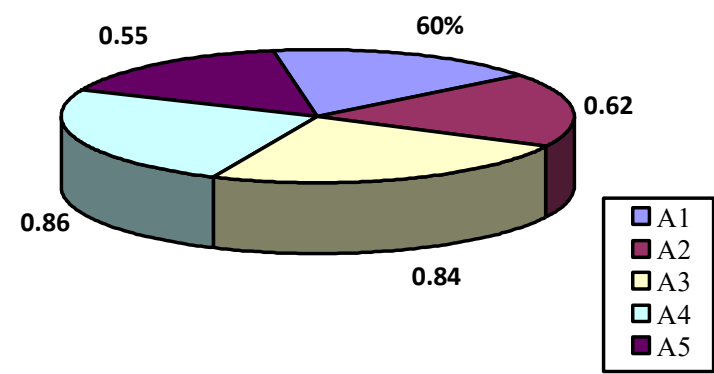

Fig.1. Application of the concept of eco office at USU Library building.

\section{Conclusions}

Five variable application of the concept of eco office that has been tested, saving electricity, saving and water conservation, waste management office, greening, other efforts, the outcome boiled down to a credit point of $67.43 \%$, which shows that the application of the concept of eco office in USU library building is quite accomplished.

\section{Acknowledgements}

This work was supported by Kemenristekdikti, and research project Penelitian Terapan 2016.

\section{References}

[1] Delinchant, B., Wurtz, F.; Schanen, J-L. and Marecchal, Y. 2016. GreEn-ER Living Lab: A Green Building with Energy Aware Occupants. In Proceedings of the 5th International Conference on Smart Cities and Green ICT Systems (SMARTGREENS 2016), pages 316-323.

[2] Green Building Council Indonesia (2010). About the Office Aspects That Can Be Said Eco Office.

[3] GBCI. 2017. Greenship. http://gbcindonesia.org/greenship

[4] Gupta, Ankush and Sharma, Aman. 2013. Green Building and Productivity. International Journal of Emerging Trends in Engineering and Development, Issue 3, Vol. 2: 179-184. 
[5] Hauser, E. 2016. How a Library Can Think Globally and Act Locally. Eco-Office Bulletin. Vol. 1, Issue. 1.

[6] Hermawan, S. Rachman and Zulfikar Zen (2006). Ethics of Librarianship: An Approach to the Profession and Code of Ethics of Indonesian Librarian. Jakarta: Sagung Seto.

[7] Higde, E. 2014. Identifying determinants of Pro-Environmental Behaviors: A case for climate change. Thesis. M.S., The Department of Elementary Science and Mathematics Education, Middle East Technical University.

[8] ISO 14005:2010. Environmental management systems -- Guidelines for the phased implementation of an environmental management system, including the use of environmental performance evaluation.

[9] Republic of Indonesia (2008). Pocket Book Ministry of Public Works Construction Development Board Construction Center Competence and Training Construction. Jakarta.

[10] Spasial. 2014. The rise of the eco-office. http://spatial.co.uk/insight/rise-eco-office/ 11 November 2014.

[11] Suresh Jain, Pallavi P. 2010 "Environmental management systems for educational institutions: A case study of TERI University, New Delhi", International Journal of Sustainability in Higher Education, Vol. 11 Issue: 3, pp.236-249.

[12] Young, W. et.all. 2013. Changing Behaviour: Successful Environmental Programmes in the Workplace. Bus. Strat. Env. Published online in Wiley Online Library. DOI: 10.1002/bse.1836 